Article

\title{
Genetic Evidence of an Isolation Barrier between Flea Subspecies of Citellophilus tesquorum (Wagner, 1898) (Siphonaptera: Ceratophyllidae)
}

\author{
Yury Ilinsky ${ }^{1,2, *}$, Vasilina Lapshina ${ }^{1}$ (D), Dmitry Verzhutsky ${ }^{3}$, Yulia Fedorova ${ }^{1}$ and Sergey Medvedev ${ }^{4}$ \\ 1 Laboratory of Molecular Genetics of Insects, Institute of Cytology and Genetics SB RAS, \\ 630090 Novosibirsk, Russia; Lapshina@bionet.nsc.ru (V.L.); i.fedorova8@g.nsu.ru (Y.F.) \\ 2 Center for Mitochondrial Functional Genomics, Immanuel Kant Baltic Federal University, \\ 236041 Kaliningrad, Russia \\ 3 Irkutsk Antiplague Institute, 664047 Irkutsk, Russia; verzh58@rambler.ru \\ 4 Parasitology Department, Zoological Institute RAS, 199034 Saint Petersburg, Russia; smedvedev@zin.ru \\ * Correspondence: paulee@bionet.nsc.ru
}

check for

updates

Citation: Ilinsky, Y.; Lapshina, V.;

Verzhutsky, D.; Fedorova, Y.;

Medvedev, S. Genetic Evidence of an Isolation Barrier between Flea

Subspecies of Citellophilus tesquorum

(Wagner, 1898) (Siphonaptera:

Ceratophyllidae). Insects 2022, 13, 126.

https://doi.org/10.3390/

insects13020126

Academic Editors: Shahid Karim and $\mathrm{Hu} \mathrm{Li}$

Received: 6 December 2021

Accepted: 23 January 2022

Published: 25 January 2022

Publisher's Note: MDPI stays neutral with regard to jurisdictional claims in published maps and institutional affiliations.

Copyright: (C) 2022 by the authors. Licensee MDPI, Basel, Switzerland. This article is an open access article distributed under the terms and conditions of the Creative Commons Attribution (CC BY) license (https:// creativecommons.org/licenses/by/ $4.0 /)$.
Simple Summary: We studied field collections of two flea subspecies that are plague vectors on the vast Palearctic territory. Analysing the molecular-genetic, geographical, morphological, and reproductive isolation criteria, we conclude that these subspecies could be considered different species.

\begin{abstract}
This study investigated the relationship between two subspecies of the Citellophilus tesquorum flea, C. t. altaicus and C. t. sungaris, which are vectors of the bacterium Yersinia pestis that causes human plague across the vast territories of the Palearctic. Adult fleas were collected from 16 localities and 11 populations in 2019 and 2020. Specimens were morphologically verified for subspecies status and analysed for mitochondrial cytochrome $c$ oxidase subunit I (COI) DNA, nuclear ribosomal cluster internal transcribed spacer 1 (ITS1) and ITS2, and Wolbachia-infection status. Our results demonstrated a genetic difference between $C$. $t$. altaicus and $C$. $t$. sungaris. According to mitochondrial data, the genetic distance between clades of C. t. altaicus and C. t. sungaris was comparable with the species divergence of the genus Callopsylla, which is closely related to Citellophilus. All studied populations of C. t. altaicus were Wolbachia-infected, whereas all studied populations of C. t. sungaris were symbiont-free. Data for ITS1 and ITS2 had much lower phylogenetic signals than mitochondrial data; however, diagnostic substitutions for C. t. altaicus and C. t. sungaris delimitation were also revealed. Analysis of a hardly accessible report on cross experiments allowed us to conclude the partial postzygotic isolation between these subspecies. Taken together, the molecular-genetic, geographical, morphological, and reproductive isolation findings verified that C. t. altaicus and C. $t$. sungaris subspecies could be considered as different species.
\end{abstract}

Keywords: Citellophilus tesquorum; COI; flea; ITS1; ITS2; plague; population; subspecies; Wolbachia

\section{Introduction}

Siphonaptera, commonly known as fleas, comprise a relatively small order of secondarily wingless insects with complete metamorphosis. According to the latest taxonomic revision, this order includes 2005 species and 828 subspecies belonging to 242 genera and 97 subgenera [1].

Fleas are vectors for many pathogens, including Rickettsia typhi (which causes endemic typhus), Rickettsia prowazekii (rural epidemic typhus) [2], Bartonella spp. (cat-scratch disease) [3], and Yersinia pestis (plague) [4]. Plague is a dangerous disease, and several hundred cases in humans are reported annually worldwide, predominantly in developing countries [4]. Developed countries have extensive systems for monitoring plague hot-spots that allow preventive actions to be taken to avoid outbreaks. Flea species differ in their 
ability to transfer plague infection. In total, 257 species are known to be reservoirs of $Y$. pestis [5,6]. Yersinia pestis bacteria inhabit the foregut of adult fleas where they form a biofilm that interferes with feeding. While trying to satisfy their hunger, infected fleas actively attack animal or human hosts, and biofilm conglomerates enter the bloodstream transmitting the infection [7].

In previous studies, the focus of researchers has been on the diversity and molecular biology of the pathogenic bacteria, whereas the flea species have been studied much less comprehensively. In terms of population genetic data, the best studied flea speciesCtenocephalides felis, Ctenocephalides canis, Pulex irritans, Tunga penetrans and Xenopsylla cheopis - are those that are synanotropic. Investigating the diversity of these species has revealed intriguing details of their evolutionary history and candidate cryptic species [8-11].

Here, we studied populations of C. tesquorum (Wagner, 1898) [12], which are active vectors of $Y$. pestis in the vast Palearctic territories [5,13]. This species parasitizes various ground squirrels (Spermophilus spp.) in the steppe and mountain regions of Southern Europe, the Caucasus, the Volga region, Central Asia, and Southern Siberia, including Transbaikal and South of Yakutia, Mongolia and Northern regions of China [6]. Nine subspecies of $C$. tesquorum have been described; however, their taxonomic status is under question, because the diagnostic morphological traits vary greatly [14-16], and genetic differences between populations in different regions are unknown.

The aim of this study was to clarify the relationship between two broadly distributed subspecies, C.t. altaicus and C. t. sungaris, which are the main active vectors in several natural plague hot-spots. These subspecies are common in the Altai, Baikalia, Yakutia, Eastern Mongolia and Outer Manchuria territories. In general, C. t. altaicus is found in the West, and C. t. sungaris is found in the East, and sympatry is noted in some Mongolian regions. Some authors previously defined C. t. sungaris as an independent C. sungaris species $[15,17,18]$. This research estimated the isolation between subspecies in order to elucidate their taxonomic status. Adult fleas were collected from populations in the Tuva, Baikalia, Transbaikalia and Yakutia territories. Analysis of the samples compared the mitochondrial DNA (mtDNA) cytochrome $c$ oxidase subunit I (COI) gene, the internal transcribed spacer 1 (ITS1) and ITS2 regions of the nuclear ribosomal gene, and the Wolbachia-infection status, which could be an additional indicator of reproductive isolation between C. t. altaicus and C. t. sungaris populations.

\section{Materials and Methods}

\subsection{Sample Collection}

We sampled adult fleas from 16 localities in 2019 and 2020 (Table 1 and Figure 1). Two methods of flea sampling were employed, both of which were conducted according to methodological guidelines MU 3.1.3012-12 of the Federal Centre for State Sanitary and Epidemiological Supervision of Rospotrebnadzor. In method one, ground squirrel nests were excavated, and fleas were collected from the nest substrates. In method two, fleas were collected from the entrances of ground squirrel burrows using a rubber hose with a fleece fabric cover; the hose was pushed several times into the burrow entrance, after which it was examined for fleas. All fleas were stored in ethanol and sent to the Laboratory of Parasitology of the Zoological Institute Russian Academy of Science, Saint Petersburg, Russia, to verify the subspecies status. Details of the subspecies morphological identification are provided in Table 2, Figures 2 and S1. Briefly, three traits of the head and abdomen were analysed to discriminate between C. t. sungaris and C. t. altaicus, as well as Citellophilus tesquorum mongolicus and Citellophilus tesquorum dzetysuensis, which were neighbour subspecies to the South (Figure 1). 
Table 1. Characteristics of data collection and Wolbachia infection.

\begin{tabular}{ccccc}
\hline $\begin{array}{c}\text { Subspecies of } \\
\text { Citellophilus tesquorum }\end{array}$ & Population & No of Localities & No of Samples & $\begin{array}{c}\text { No of Wolbachia } \\
\text { Infected Samples }\end{array}$ \\
\hline sungaris & Goloustnenskaya & 3 & 7 & 0 \\
\hline sungaris & Ust-Ordynskaya & 2 & 7 & 0 \\
\hline sungaris & East Torean & 2 & 19 & 0 \\
\hline sungaris & Kudinskaya & 1 & 4 & 0 \\
\hline sungaris & Yakutskaya & 1 & 15 & 15 \\
\hline altaicus & Ulug-Khemskaya & 1 & 9 & 7 \\
\hline altaicus & Saglinskaya & 1 & 20 & 9 \\
\hline altaicus & Karginskaya & 2 & 6 & 3 \\
\hline altaicus & Despenskaya & 1 & 6 & 3 \\
\hline altaicus & Boro-Shaiskaya & 1 & 5 & 3 \\
\hline altaicus & Chozinskaya & 1 & & 0 \\
\hline
\end{tabular}

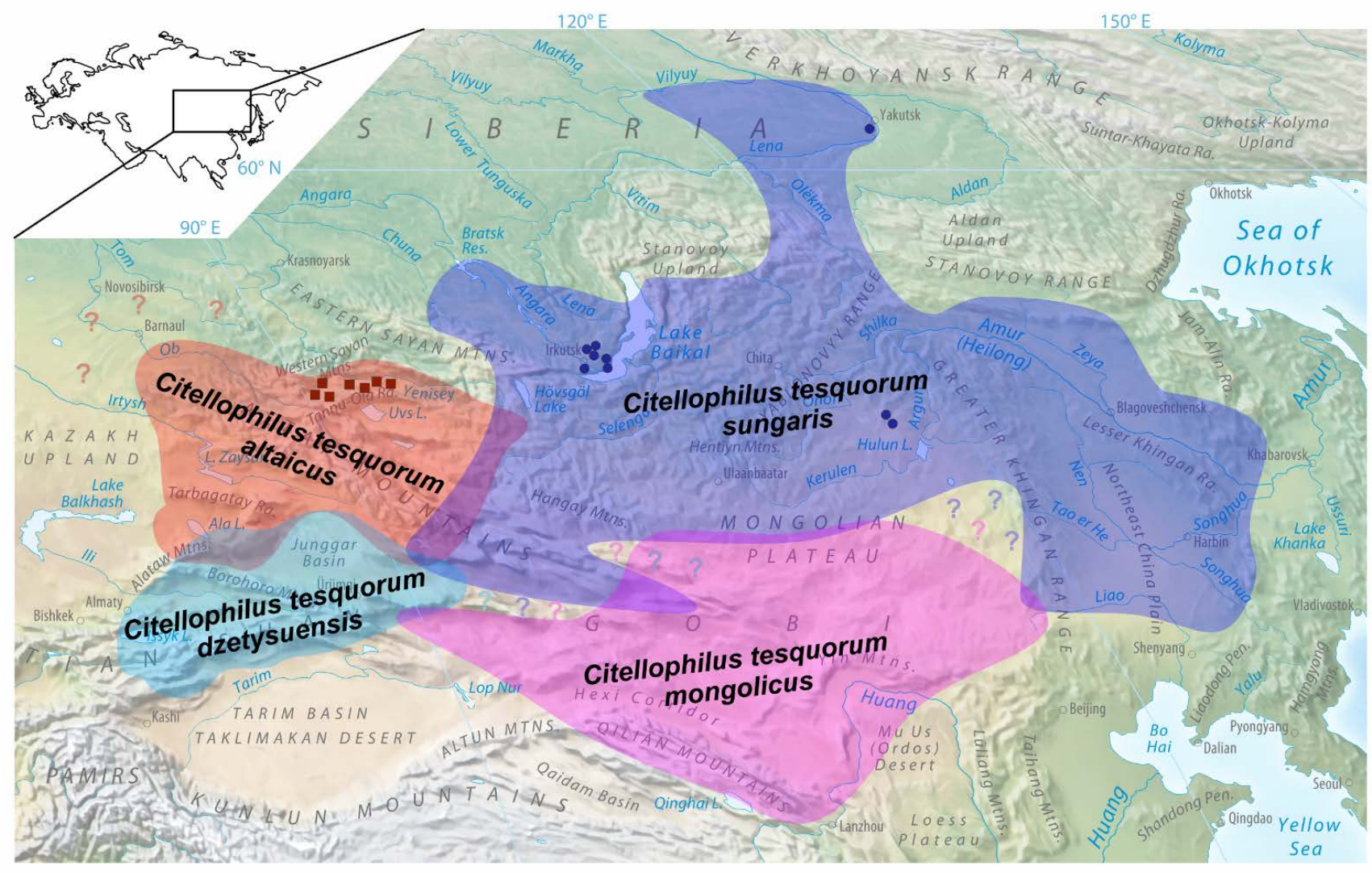

Figure 1. Ranges of four Citellophilus tesquorum subspecies. The map based on Tan, Shen [13], and Verzhutsky et al. [19]. 
Table 2. Morphological delimitation traits of four Citellophilus tesquorum subspecies.

\begin{tabular}{|c|c|c|c|c|}
\hline Trait & C.t. altaicus & C.t. sungaris & C.t. mongolicus & C.t.dzetysuensis \\
\hline $\begin{array}{l}\text { Head: ratio of proboscis } \\
\text { apex to coxa } \\
\text { and trochanter }\end{array}$ & $\begin{array}{l}\text { reach apex of coxa, or } \\
\text { middle of trochanter } \\
\text { (Figure } 2 \mathrm{~A})\end{array}$ & $\begin{array}{l}\text { reach apex of trochanter } \\
\text { (Figure 2B) }\end{array}$ & $\begin{array}{l}\text { reach middle or apex } \\
\text { of trochanter }\end{array}$ & reach middle of trochanter \\
\hline $\begin{array}{l}\text { Abdomen: presence of } \\
\text { membranous appendage } \\
\text { of sternum VIII apical part }\end{array}$ & $\begin{array}{c}\text { present } \\
\text { (Figures 2C and S1A) }\end{array}$ & $\begin{array}{c}\text { absent } \\
\text { (Figures 2D and S1C) }\end{array}$ & absent (Figure S1D) & absent (Figure S1B) \\
\hline $\begin{array}{l}\text { Abdomen: presence of } \\
\text { lateral sinus of posterior } \\
\text { margin sternum VIII }\end{array}$ & $\begin{array}{c}\text { absent } \\
\text { (Figures 2E and S1E) }\end{array}$ & $\begin{array}{l}\text { present or absent } \\
\text { (Figures } 2 \mathrm{~F} \text { and S1G) }\end{array}$ & present (Figure S1H) & no data (Figure S1F) \\
\hline
\end{tabular}
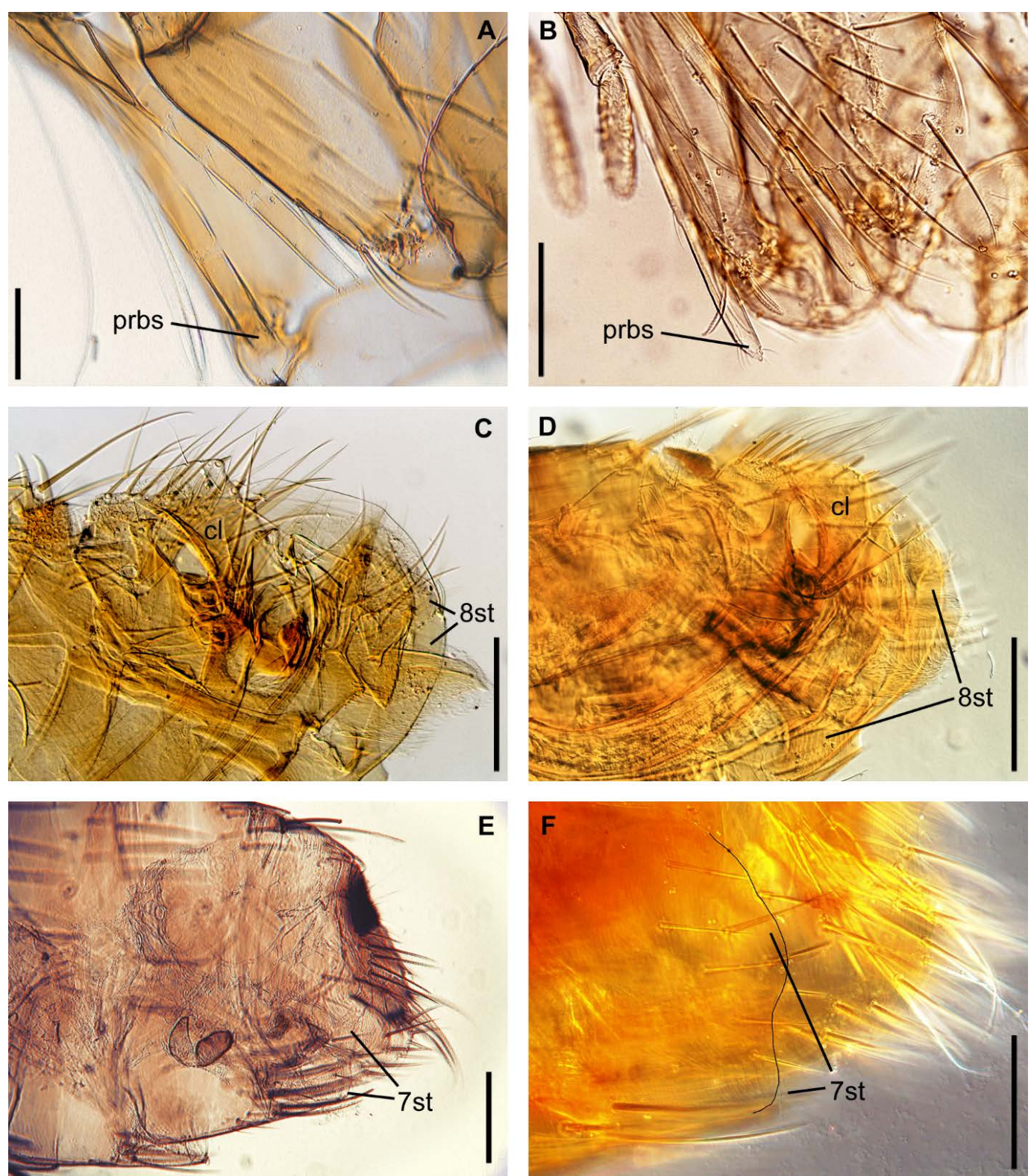

Figure 2. Diagnostic characteristics of Citellophilus tesquorum subspecies. Head: ratio of proboscis (prbs) apex to coxa of (A) C. t. altaicus and (B) C. t. sungaris. Abdomen: clasper (cl) and sternum VIII (8st) of (C) C. t. altaicus and (D) C. t. sungaris. Abdomen: outline of sternum VII (7st) of (E) C. $t$. altaicus and (F) C. t. sungaris. Scale bars $=0.1 \mathrm{~mm}$. 
Before and after morphological verification, the samples were stored in $96 \%$ ethanol. The DNA analysis was carried out in the Laboratory of Molecular Genetics of Insects at the Institute of Cytology and Genetics, Novosibirsk, Russia. In total, 61 samples of C. t. altaicus and 42 samples of C. t. sungaris were used in the molecular study.

\subsection{DNA Extraction, Amplification and Sequencing}

Fleas were individually homogenized in $200 \mu \mathrm{L}$ of extraction buffer $(10 \mathrm{mM}$ TRIS-HCl [pH 8.0], $25 \mathrm{mM}$ ethylenediaminetetraacetic acid (EDTA), 0.5\% sodium dodecyl sulphate (SDS), $0.1 \mathrm{M} \mathrm{NaCl}$, and $0.1 \mathrm{mg} / \mathrm{mL}$ proteinase $\mathrm{K}$ ) and incubated for $2 \mathrm{~h}$ at $56{ }^{\circ} \mathrm{C}$. The DNA extract was precipitated and diluted in $200 \mu \mathrm{L}$ of deionised water. One microliter of DNA solution was used for amplification. Three genetic markers were investigated: the nuclear region including ITS1, ITS2, and 5.8S ribosomal RNA (rRNA); the mitochondrial locus COI; and the Wolbachia-infection status. The mitochondrial locus was amplified with the primer set LCO-1490/HCO-2198 [20]. The nuclear marker was amplified with primers that flanked the $18 \mathrm{~S}$ and $28 \mathrm{~S}$ regions as a whole product (2075 base pairs [bp]), or using two overlapping fragments with primers that flanked the $18 \mathrm{~S}$ and $5.8 \mathrm{~S}$ regions and the $5.8 \mathrm{~S}$ and $28 \mathrm{~S}$ regions; the fragments were sequenced with the primers listed in Table 3. All PCR reactions were performed using BioMaster HS-Taq PCR $(2 \times)$ (BiolabMix, Novosibirsk, Russia) with a $20 \mu \mathrm{L}$ volume. The PCR cycling conditions were as follows: initial denaturation $5 \mathrm{~min}$ at $95^{\circ} \mathrm{C}$; 35 cycles of denaturing at $95{ }^{\circ} \mathrm{C} 15 \mathrm{~s}$, annealing at $55^{\circ} \mathrm{C}$ for ribosomal DNA and $53{ }^{\circ} \mathrm{C}$ for mitochondrial DNA $30 \mathrm{~s}$, elongation at $72{ }^{\circ} \mathrm{C} 30 \mathrm{~s}-1 \mathrm{~min} 30 \mathrm{~s}$ depending on the expected amplicon size; and final elongation at $72{ }^{\circ} \mathrm{C}-3 \mathrm{~min}$. All specimens were examined for Wolbachia infection by the nested PCR with the primer set ftsZuniv1/2 for the first round and ftsZf1/r1 for the second round (for details, see [21]). DNA samples of Drosophila melanogaster stocks infected with Wolbachia and uninfected [22] were used as positive and negative controls. The PCR products were visualised on agarose gel (1.5\%) electrophoresis. Amplicons were purified by exonuclease I of Escherichia coli (ExoI; New England Biolabs) and sequenced by the BrightDye Terminator Cycle Sequencing kit (Nimagen). Sequences were deposited in the GenBank under accession numbers OL484862-OL484880 for ITS1 and ITS2, and OL504533-OL504557 for COI.

Table 3. Primers used in the study.

\begin{tabular}{|c|c|c|c|}
\hline Primer & Target & $5^{\prime}-3^{\prime}$ Sequence & Reference \\
\hline ITS5-f1 & ribosomal region & GGAAGTAAAAGTCGTAACAAGG & [23] \\
\hline ITS2-r2 & ribosomal region & CAAGGTTTCCGTAGGTGAACCTG & [24] \\
\hline ITS1ctf2 & ribosomal region & CGCGTACAGGCAGATTATCA & this study \\
\hline ITS1ctr2 & ribosomal region & GCCCGCACTCAAACATTAAA & this study \\
\hline ITS1ctf & ribosomal region & CGTGCTTCGGTGTGTGTTTT & this study \\
\hline ITS1ctr & ribosomal region & GGACAAATTCGCTCTCACGC & this study \\
\hline ITS2-f2 & ribosomal region & GGGTCGATGAAGAACGCAGC & [25] \\
\hline ITS1-r1 & ribosomal region & GCTGCGTTCTTCATCGACCC & {$[26]$} \\
\hline ITS2-f3 & ribosomal region & GACCACTCCTGGCTGAGG & this study \\
\hline ITS1-r2 & ribosomal region & CCAGGAGTGGTCCGGGAACAGTATC & this study \\
\hline $28 S-r 2$ & ribosomal region & TAGTTTCTTTTCCTCCGCTTAA & this study \\
\hline 28S-r1 & ribosomal region & GCCGCTACTAAGGGAATCCTA & this study \\
\hline HCO-2198 & COI, mitochondrial gene & TAAACTTCAGGGTGACCAAAAAATCA & {$[20]$} \\
\hline LCO-1490 & COI, mitochondrial gene & GGTCAACAAATCATAAAGATATTGG & {$[20]$} \\
\hline ftsZuniv1 & Wolbachia symbiont & GG(CT)AA(AG)GGTGC(AG)GCAGAAGA & [27] \\
\hline ftsZuniv2 & Wolbachia symbiont & ATC(AG)AT(AG)CCAGTTGCAAG & {$[27]$} \\
\hline $\mathrm{ftsZf1}$ & Wolbachia symbiont & ATYATGGARCATATAAARGATAG & [28] \\
\hline $\mathrm{ftsZr1}$ & Wolbachia symbiont & TCRAGYAATGGATTRGATAT & [28] \\
\hline
\end{tabular}




\subsection{Evolutionary Analysis}

In addition to our data, we used sequences deposited in the GenBank database by other authors; in particular, we retrieved the following accession numbers: EU770311-14 for the analysis of ITS variation; and MG138174, 77, 78, 80 to 83, 91 and 92 (Callopsylla spp.), KM890971, and MF000642 (C. tesquorum) for the mtDNA variation. Alignments were generated by the MUSCLE algorithm [29]. DNA polymorphism comprising number of polymorphic sites (S), number of haplotypes (h), haplotype diversity (Hd), nucleotide diversity $(\mathrm{Pi})$ and the fixation index $\left(\mathrm{F}_{\mathrm{ST}}\right)$ were calculated using DnaSP v5 [30]. The maximum likelihood (ML) phylogenetic tree for the mtDNA data was reconstructed in Mega6, and the coefficient of differentiation $\left(\mathrm{G}_{\mathrm{ST}}\right)$ was calculated [31]. A Templeton, Crandall, and Sing (TCS) gene network [32] was produced by PopArt [33] to represent the genealogical relationships among alleles of nuclear ribosomal genes and their frequencies. An allele of the Wolbachia ftsZ locus was checked in the Public Databases for Molecular Typing and Microbial Genome Diversity (PubMLST) [34].

\section{Results}

Fleas were collected in 16 localities from 11 populations. The geographical boundaries of the host and flea populations were considered to be the same [35]. Morphological identification of the subspecies status was in agreement with the expectation; five eastern populations were represented by $C$. $t$. sungaris and six western populations by C. $t$. altaicus. DNA was extracted from 103 fleas: in total, 42 samples were C. $t$. sungaris and 61 were C. t. altaicus. All DNA samples were of good quality for PCR analysis, which was checked by amplification with the universal primers LCO-1490/HCO-2190. The full dataset was examined for Wolbachia-infection status by nested PCR for bacterial locus ftsZ. All populations of C. t. sungaris were Wolbachia-negative, whereas all populations of C. $t$. altaicus were Wolbachia-positive, giving a total of $66 \%$ infected samples (Table 1 ). The analysed Wolbachia isolates were characterised by the ftsZ-56 allele clustered into the A-supergroup (Figure S2), which is common for insects [28].

We sequenced the mitochondrial locus COI with the universal primer set of at least one sample for each population. The analysis of alignment ( 25 samples, $587 \mathrm{bp}$ ) revealed values of $S=57$ and $h=19$; all replacements were synonymous. The values for the Hd and Pi diversity of the entire population were 0.967 and 0.041 , respectively. The values of these indices for the subspecies were as follows: for $C$. $t$. sungaris, $S=18, \mathrm{~h}=8, \mathrm{Hd}=0.885$ and $\mathrm{Pi}=0.013$; and for C. . altaicus, $\mathrm{S}=25, \mathrm{~h}=11, \mathrm{Hd}=0.985$ and $\mathrm{Pi}=0.014$. The $\mathrm{F}_{\mathrm{ST}}$ and $\mathrm{G}_{\mathrm{ST}}$ were 0.794 and 0.668 , respectively, indicating a high isolation level between subspecies. The p-distance between the populations of subspecies was 0.066 .

The ML phylogenetic tree of the mtDNA data (Figure 3) had two clades: the first included all C. $t$. altaicus and C. $t$. dzetysuensis retrieved from the GenBank database (MF000642); and the second included only C.t. sungaris samples. Therefore, the components of maternal inheritance (mtDNA variation and Wolbachia infection) indicated isolation between C.t. sungaris and C. t. altaicus.

To estimate the differentiation between subspecies according to nuclear genes, we sequenced the ITS1 and ITS2 and located 5.8S rRNA locus between them. As with the mtDNA variation analysis, we aimed to obtain sequences from all populations. However, ITS1 and ITS2 variation was very low, so we sequenced only 19 samples. Despite the low variation, the observed polymorphism subdivided the C. t. altaicus and C. $t$. sungaris samples. The length of the nuclear sequences was in the range of 1999 to $2001 \mathrm{bp}$. Five sites were characterised by an ambiguous signal that could be explained by errors in sequencing or by heterozygosity, so they were excluded from the analysis. Three isolates of C. t. altaicus and three of C. t. dzetysuensis were retrieved from the GenBank and added to the analysis. The final alignment of 25 samples comprised 1968 bp (Figure 4) and was characterised by the following parameters: $\mathrm{S}=12, \mathrm{~h}=6, \mathrm{Hd}=0.700$ and $\mathrm{Pi}=0.00176$. The $\mathrm{F}_{\mathrm{ST}}$ and $\mathrm{G}_{\text {ST }}$ values between the samples of C. $t$. altaicus and C. $t$. sungaris were 1.0, demonstrating complete isolation between the subspecies (see the Supplementary Material). 


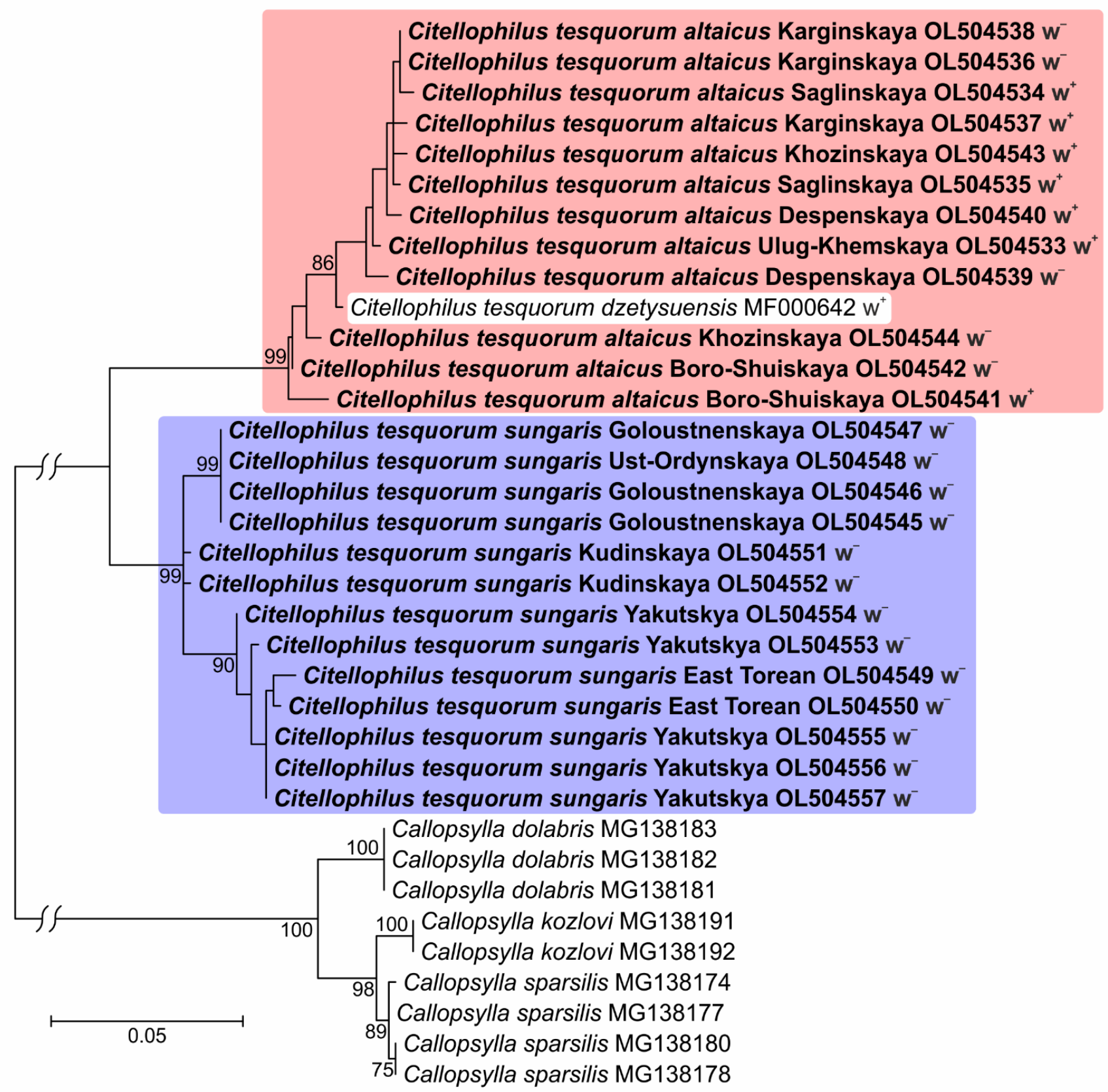

Figure 3. ML-phylogenetic tree of Citellophilus tesquorum altaicus, C. t. sungaris, C. t. dzetysuensis, and Calopsylla spp. mtDNA based on 587 bp of COI sequences (isolates included in this study are shown in bold). GenBank accession numbers, name of flea populations, Wolbachia-infection status $\left(\mathrm{w}^{+}=\right.$infected; $\mathrm{w}^{-}=$uninfected $)$and bootstrap values (1000 iterations) greater than 70 are provided . 


\begin{tabular}{|c|c|c|c|c|c|c|c|c|c|c|c|c|c|c|c|c|c|c|c|c|c|}
\hline Sample & $\begin{array}{l}1 \\
6\end{array}$ & $\begin{array}{l}1 \\
8\end{array}$ & $\begin{array}{l}3 \\
1 \\
1\end{array}$ & $\begin{array}{l}3 \\
1 \\
7\end{array}$ & $\begin{array}{l}3 \\
2 \\
1\end{array}$ & $\begin{array}{l}4 \\
2 \\
0\end{array}$ & $\begin{array}{l}6 \\
9 \\
5\end{array}$ & $\begin{array}{l}2 \\
5 \\
0\end{array}$ & $\begin{array}{l}2 \\
5 \\
1\end{array}$ & $\begin{array}{l}2 \\
5 \\
2\end{array}$ & $\begin{array}{l}2 \\
5 \\
3\end{array}$ & $\begin{array}{l}2 \\
5 \\
4\end{array}$ & $\begin{array}{l}2 \\
5 \\
5\end{array}$ & $\begin{array}{l}5 \\
3 \\
2\end{array}$ & $\begin{array}{l}5 \\
3 \\
6\end{array}$ & $\begin{array}{l}7 \\
3 \\
0\end{array}$ & $\begin{array}{l}9 \\
4 \\
9\end{array}$ & $\begin{array}{l}9 \\
5 \\
4\end{array}$ & $\begin{array}{l}9 \\
5 \\
7\end{array}$ & $\begin{array}{l}9 \\
5 \\
9\end{array}$ & 6 \\
\hline Consensus & $\mathrm{T}$ & $\mathrm{T}$ & A & G & $\mathrm{T}$ & A & $\mathrm{T}$ & $\mathrm{T}$ & C & G & G & $\mathrm{T}$ & $T$ & A & $\mathrm{T}$ & $\mathrm{G}$ & $\mathrm{G}$ & G & G & A & $\mathrm{T}$ \\
\hline OL484869 & . & . & G & A & & & . & $\cdot$ & . & . & 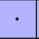 & 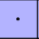 & . & . & - & - & A & 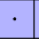 & 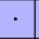 & 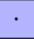 & \\
\hline OL484870 & . & . & G & $A$ & . & - & . & . & . & - & . & . & . & . & . & . & A & 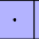 & $\cdot$ & . & \\
\hline OL484871 & - & . & G & A & - & . & $\cdot$ & . & . & . & . & . & . & . & . & . & A & . & - & . & - \\
\hline OL484872 & . & . & G & A & . & . & . & $\cdot$ & . & . & . & . & $\cdot$ & . & . & . & A & . & . & . & . \\
\hline OL484873 & - & . & G & A & . & - & . & $\cdot$ & . & . & . & - & - & . & . & . & A & . & . & $\cdot$ & . \\
\hline OL484874 & - & . & G & A & . & . & . & $\cdot$ & . & . & . & . & . & . & . & . & A & 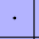 & . & $\cdot$ & . \\
\hline OL484875 & . & . & G & A & . & . & . & $\cdot$ & . & $\cdot$ & . & . & . & . & . & . & A & . & . & $\cdot$ & . \\
\hline OL484876 & . & . & $G$ & $A$ & . & . & . & . & . & . & . & . & . & . & . & . & A & . & . & . & . \\
\hline OL484877 & . & . & G & A & . & . & . & $\cdot$ & $\cdot$ & . & . & . & . & . & . & . & A & $\cdot$ & . & $\cdot$ & . \\
\hline OL484879 & . & . & $\mathrm{G}$ & A & . & . & . & $\cdot$ & . & $\cdot$ & . & . & $\cdot$ & . & . & . & A & . & . & $\cdot$ & . \\
\hline OL484880 & . & . & G & A & . & . & . & $\cdot$ & . & $\cdot$ & . & . & $\cdot$ & . & . & . & A & . & . & . & · \\
\hline OL484862 & - & . & . & . & - & . & . & . & . & . & . & . & $\cdot$ & . & . & . & . & . & . & $\cdot$ & . \\
\hline OL484863 & . & . & . & . & - & . & . & $\cdot$ & . & $\cdot$ & . & . & . & . & . & . & . & . & . & $\cdot$ & . \\
\hline OL484864 & . & . & . & . & - & . & . & $\cdot$ & $\cdot$ & $\cdot$ & . & $\cdot$ & $\cdot$ & . & . & . & . & . & . & $\cdot$ & . \\
\hline OL484865 & . & . & . & . & - & . & . & $\cdot$ &. & . & . & . &. & . & . & . & . & . & . & $\cdot$ & $\cdot$ \\
\hline OL484866 & - & . & . & . & - & $\cdot$ & $\cdot$ & $\cdot$ & . & $\cdot$ & . & $\cdot$ & $\cdot$ & . & . & . & . & . & . & $\cdot$ & . \\
\hline OL484867 & . & . & . & . & - & $\cdot$ & $\cdot$ & $\cdot$ & . & . & . & $\cdot$ & $\cdot$ & . & . & . & . & . & . & $\cdot$ & . \\
\hline OL484868 & . & . & . & . & - & . & . & $\cdot$ & . & . & . & $\cdot$ & $\cdot$ & . & . & . & . & . & . & $\cdot$ & . \\
\hline EU770314 & . & . & . & . & - & $\mathrm{C}$ & . & - & - & - & - & - & - & . & . & . & $\mathrm{T}$ & C & A & $\cdot$ & . \\
\hline EU770315 & . & . & . & . & - & C & . & - & - & - & - & - & - & . & . & . & $\mathrm{T}$ & C & A & $\cdot$ & $\cdot$ \\
\hline EU770316 & $\dot{\circ}^{\circ}$ & . & . & . & - & $\mathrm{C}$ & . & - & - & - & - & - & - & . & . & . & $\mathrm{T}$ & C & A & $\cdot$ & $\cdot$ \\
\hline EU770311 & A & A & . & . & - & $\cdot$ & C & $\cdot$ & . & $\cdot$ & $\cdot$ & $\cdot$ & $\cdot$ & . & . & . & $\mathrm{T}$ & C & A & $\cdot$ & $\cdot$ \\
\hline EU770312 & . & $\cdot$ & . & . & - & C & C & $\cdot$ & . & . & $\cdot$ & $\cdot$ & $\cdot$ & . & . & . & $\mathrm{T}$ & $C$ & A & . & . \\
\hline EU770313 & . & . & . & . & - & $\cdot \cdot$ & $\cdot$ & . & . & - & . & . & . & . & . & . & $\mathrm{T}$ & $\mathrm{C}$ & $\mathrm{A}$ & $T$ & A \\
\hline
\end{tabular}

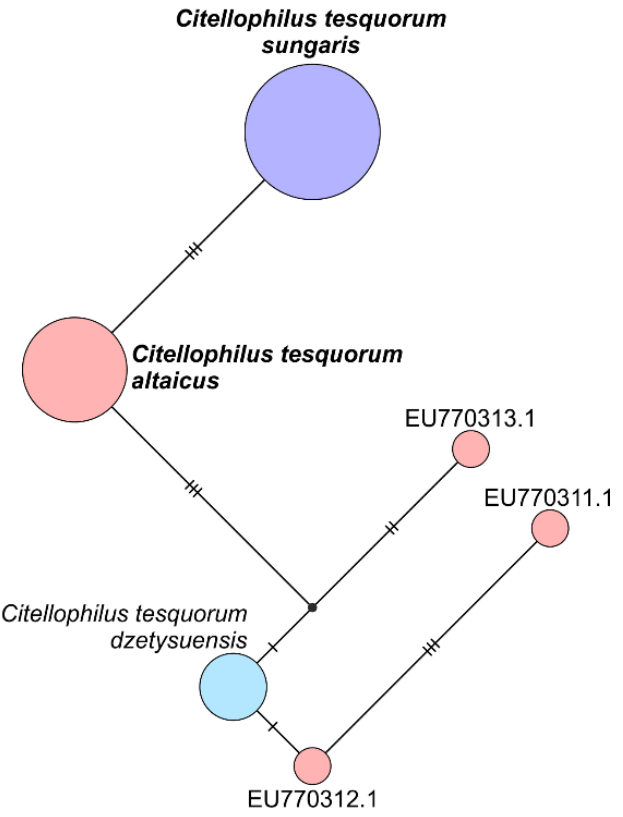

Figure 4. A-Nucleotide polymorphisms of ITS1 and ITS2 for Citellophilus tesquorum altaicus, C. $t$. sungaris and C. t. dzetysuensis (highlighted in accordance with Figure 1). Bold GenBank numbers indicate those included in this study. The number of polymorphic sites is indicated after excluding ambiguous positions from the alignment. B-Relationships (TCS network) of rRNA alleles reconstructed by PopArt.

\section{Discussion}

Traditional morphological analyses combined with molecular-genetic investigation is a powerful approach to clarify relationships at the species level. In previous studies of fleas, notable results were obtained for $C t$. felis whereby the subspecies $C t$. f. orientalis was reclassified as the species $C$ t. orientalis [8,9], and Ct.f. felis and Ct.f. strongylus were found to be synonymous [36]. Based on a conflict of genetics and phenotype variation, a wide morphological plasticity was found in females of the genus Ctenophthalmus [37]. Moreover, two cryptic lineages (species) were identified within Pulex irritans [11].

Our results clearly demonstrated genetic differences between C. t. altaicus and C. t. sungaris. The most evident divergence of these subspecies was observed in their mtDNA data. The genetic distance between the clades of C. t. altaicus and C. t. sungaris was comparable to the species divergence within the Callopsylla genus, which is closely related to Citellophilus. In addition, the sequences of C. t. dzetysuensis and C. t. mongolicus derived by other authors clustered into the C. t. altaicus clade (Figure S3). The data for ITS1 and ITS2 showed much weaker phylogenetic signals. Only three replacements and one indel were found per $2 \mathrm{Kbp}$; however, they were diagnostic for C. t. altaicus and C. t. sungaris divergence. Additional isolates of C. t. altaicus and C. t. dzetysuensis deposited in GenBank showed even greater divergence from C. t. sungaris (Figure 4). Finally, the populations of C. t. sungaris differed from C. t. altaicus in Wolbachia-infection status. The symbiont was found in all populations of C. t. altaicus, and Wolbachia infection was found in C. t. dzetysuensis (MF045776-MF045779 and MF04583-MF045786). Notably, Wolbachia infection is often associated with flea diversity as summarized by Yudina et al. [38]. The sequence 
of the Wolbachia ftsZ gene isolated from C. t. altaicus in our isolates was clustered into the A-supergroup. The analysis of the wsp locus of Wolbachia isolated from C. t. dzetysuensis revealed two types of symbionts clustered also into the A-supergroup (Figure S2).

A crucial element of species discrimination is reproductive isolation. We analysed a hardly accessible report on reciprocal crosses of C. $t$. altaicus and C. $t$. sungaris [39] (see Supplementary Materials). In both cross directions, the number of $\mathrm{F}_{1}$ progeny per female was in the range of 1.2-6.4, whereas in the control crosses (within subspecies) it was 45.4-51.0. Low fertility (2.0-5.4) was also observed in the $\mathrm{F}_{2}$ progeny. This indicated incomplete postzygotic isolation between the subspecies. The authors noted that the hybrids were slightly larger than the parents, demonstrating higher rates of fluctuating asymmetry and morphoses. The hybrids were also tested to produce a biofilm of Y. pestis and to infect laboratory animals [40]. Both parameters were higher in the progeny than in the parent subspecies. These features could decrease hybrid fitness in the field via more effective infection of the host population and increased starvation levels due to Y. pestis infection.

Taken together, the molecular-genetic, geographical, morphological and reproductive isolation data indicate that the C. t. altaicus and C. t. sungaris are long-term isolated and could be considered different species. Even from a sceptical perspective, the subspecies features clearly indicate a case of incomplete speciation. Here, it is important to mention that Jordan [17], Cyprich et al. [18] and Lewis [15] provided C. t. sungaris as the independent species C. sungaris.

The next step for our research will be to clarify the relationships among the other subspecies of $C$. tesquorum. Preliminary results based on the limited sequences retrieved from the GenBank database indicate that C. t. mongolicus and C. t. dzetysuensis do not show significant differences from C. t. altaicus. However, genetic data on Eastern European and Caucasian populations are lacking to date.

Supplementary Materials: The following are available online at https:/ /www.mdpi.com/article/10 .3390/insects13020126/s1, S1. Pdf file of the article: Nikitin A.Ya., Nechaeva L.K. Hybridization of flea subspecies as a possible basis for the method of regulating the number of vectors. //Organization of plague surveillance and prevention measures. Mater. Interstate Scientific and Practical ConferenceAlma-Ata (in Russian)._-1992. 3. 400-403; S2. Pdf file of the article: Nikitin A.Ya., Bazanova L.P., Nechaeva L.K., Korzun V.M., Khabarov A.V., Kozets L.I. Experimental study of the ability of hybrids bred from two subspecies of the flea Citellophilus tesquorum to transmit plague bacillus. / / Medical Parasitology and Parasitic Diseases (in Russian).-1995. 4. 15-17; Figure S1. Diagnostic features of Citellophilus tesquorum subspecies; Figure S2. Phylogenetic relationships of $\mathrm{ftsZ}$ and wsp Wolbachia allels; Figure S3. Phylogenetic tree of a 404-bp region of the COI gene reconstructed by the maximum likelihood method based on the T92 + I model. All bootstrap (100 iterations) values are indicated.

Author Contributions: Conceptualization, Y.I. and S.M.; methodology, Y.I., V.L., D.V., Y.F. and S.M.; validation, Y.I. and S.M.; formal analysis, Y.I., V.L., Y.F. and S.M.; investigation, Y.I., V.L., Y.F. and S.M.; resources, Y.I. and S.M.; data curation, Y.I. and S.M.; writing-original draft preparation, Y.I.; writing-review and editing, Y.I.; visualization, Y.I. and S.M.; supervision, Y.I. and S.M.; funding acquisition, S.M. All authors have read and agreed to the published version of the manuscript.

Funding: This work was supported by the Russian Foundation Basic Research Grant No. 19-0400759, and the Ministry of Science and Higher Education of the Russian Federation Grants No. 121031800061-7 (Y.I., V.L. and Y.F.) and AAAA-A19-119020790133-6 (S.M.).

Institutional Review Board Statement: Not applicable.

Informed Consent Statement: Not applicable.

Data Availability Statement: The data presented in this study are available in article or Supplementary Materials.

Acknowledgments: We are grateful to Andrey Broshkov for technical support and to four anonymous reviewers for valuable comments and suggestions.

Conflicts of Interest: The authors declare no conflict of interest. 


\section{References}

1. Medvedev, S.G.; Lobanov, A.L.; Lyanguzov, I.A. World Database of Fleas (Nov 2004 version). In Species-2000 E ITIS Catalogue of Life-2005 Annual Checklist [CD-ROM]; Bisby, F.A., Ruggiero, M.A., Wilson, K.L., Cachuela-Palacio, M., Kimani, S.W., Roskov, Y.R., Soulier-Perkins, A., van Hertum, J., Eds.; Species 2000: Reading, UK, 2005.

2. Bitam, I.; Dittmar, K.; Parola, P.; Whiting, M.F.; Raoult, D. Fleas and flea-borne diseases. Int. J. Infect. Dis. 2010, 14, e667-e676. [CrossRef] [PubMed]

3. Zangwill, K.M. Cat Scratch Disease and Bartonellaceae: The Known, the Unknown and the Curious. Pediatric Infect. Dis. J. 2021, 40, S11-S15. [CrossRef] [PubMed]

4. Glatter, K.A.; Finkelman, P. History of the plague: An ancient pandemic for the age of COVID-19. Am. J. Med. 2021, 134, 176-181. [CrossRef] [PubMed]

5. Dubyanskiy, V.M.; Yeszhanov, A.B. Ecology of Yersinia pestis and the epidemiology of plague. In Yersinia Pestis: Retrospective and Perspective; Advances in Experimental Medicine and Biology; Yang, R., Anisimov, A., Eds.; Springer: Berlin, Germany, 2016; Volume 918, pp. 101-170.

6. Medvedev, S.G.; Kotti, B.K.; Verzhutsky, D.B. Diversity of Fleas (Siphonaptera), Vectors of Plague Pathogens: The Flea Citellophilus tesquorum (Wagner, 1898), a Parasite of Ground Squirrels of the Genus Spermophilus. Entomol. Rev. 2019, 99, 565-579. [CrossRef]

7. Hinnebusch, B.J.; Chouikha, I.; Sun, Y.C. Ecological opportunity, evolution, and the emergence of flea-borne plague. Infect. Immun. 2016, 84, 1932-1940. [CrossRef]

8. Lawrence, A.L.; Brown, G.K.; Peters, B.; Spielman, D.S.; Morin-Adeline, V.; Šlapeta, J. High phylogenetic diversity of the cat flea (Ctenocephalides felis) at two mitochondrial DNA markers. Med. Vet. Entomol. 2014, 28, 330-336. [CrossRef]

9. Lawrence, A.L.; Hii, S.; Jirsová, D.; Panáková, L.; Ionică, A.M.; Gilchrist, K.; Modrý, D.; Mihalca, A.D.; Webb, C.E.; Traub, R.J.; et al. Integrated morphological and molecular identification of cat fleas (Ctenocephalides felis) and dog fleas (Ctenocephalides canis) vectoring Rickettsia felis in central Europe. Vet. Parasitol. 2015, 210, 215-223. [CrossRef]

10. Zhao, F.; Zhang, T.; Su, J.; Huang, Z.; Wu, A.; Lin, G. Genetic differentiation of the oriental rat flea, Xenopsylla cheopis, from two sympatric host species. Parasites Vectors 2018, 11, 1-6. [CrossRef]

11. Zurita, A.; Callejón, R.; García-sánchez, Á.M.; Urdapilleta, M.; Lareschi, M.; Cutillas, C. Origin, evolution, phylogeny and taxonomy of Pulex irritans. Med. Vet. Entomol. 2019, 33, 296-311. [CrossRef]

12. Wagner, J. Aphanipterologische Studien. III. Ueber die Gattung Pulex und Beschreibungneuer Arten der Gattungen Ceratophyllus, Ctenopsylla, Ceratopsylla und Typhlopsylla. Trudy Russk. Ent. Obshch. 1898, 31, 555-594.

13. Tan, J.A.; Shen, E.L. The Atlas of Plague and Its Environment in the People's Republic of China; Science Press: Beijing, China, 2000.

14. Traub, R.E.; Rothschild, M.; Haddow, J.F. The Ceratophyllidae: Key to the genera and host relationships, with notes on their evolution, zoogeography and medical importance; Cambridge University Press: Cambridge, UK, 1983; p. 288.

15. Lewis, R.E. The Ceratophyllidae: Currently accepted valid taxa (Insecta: Siphonaptera). In Koenigstein, Koeltz Scientific Books; Koeltz: Koenigstein, Germany, 1990; p. 267.

16. Lewis, R.E. Siphonaptera, 15th ed.; Iowa State University: Ames, IA, USA, 2003; p. 62.

17. Jordan, K. On fleas collected by Dr. H. M. Jettmar in Mongolia and Manchuria in 1927 and 1928. Novit. Zool. 1929, 34, 155-164.

18. Cyprich, D.; Kiefer, M.; Krumpal, M. Revision of the genus Citellophilus (Siphonaptera) from Mongolia. Acta Fac. Ferum Nat. Univ. Comen. Zool. 1985, 28, 33-56.

19. Verzhutsky, D.B.; Verzhutskaya, J.u.A.; Kholin, A.V.; Medvedev, S.G. The boundary of the areas of two subspecies of fleasParasites of Ground squirrels (Citellophilus tesquorum sungaris and Citellophilus tesquorum altaicus). Baikalskij Zool. Žurnal 2021, 1, 116-120.

20. Folmer, O.; Black, M.; Hoeh, W.; Lutz, R.; Vrijenhoek, R. DNA primers for amplification of mitochondrial cytochrome C oxidase subunit I from diverse metazoan invertebrates. Mol. Mar. Biol. 1994, 3, 294-299.

21. Bykov, R.; Kerchev, I.; Demenkova, M.; Ryabinin, A.; Ilinsky, Y.Y. Sex-Specific Wolbachia Infection Patterns in Populations of Polygraphus proximus Blandford (Coleoptera; Curculionidae: Scolytinae). Insects 2020, 11, 547. [CrossRef]

22. Ilinsky, Y. Coevolution of Drosophila melanogaster mtDNA and Wolbachia genotypes. PLoS ONE 2013, 8, e54373. [CrossRef]

23. White, T.J.; Bruns, T.; Lee, S.J.; Taylor, J. Amplification and direct sequencing of fungal ribosomal RNA genes for phylogenetics. In PCR Protocols: A Guide to Methods and Applications; Academic Press: Cambridge, MA, USA, 1990; Volume 18, pp. 315-322.

24. Gamerschlag, S.; Mehlhorn, H.; Heukelbach, J.; Feldmeier, H.; D'Haese, J. Repetitive sequences in the ITS1 region of the ribosomal DNA of Tunga penetrans and other flea species (Insecta, Siphonaptera). Parasitol. Res. 2008, 102, 193-199. [CrossRef]

25. Navajas, M.; Gutierrez, J.; Bonato, O.; Bolland, H.R.; Mapangou-Divassa, S. Intraspecific diversity of the cassava green mite Mononychellus progresivus (Acari: Tetranychidae) using comparisons of mitochondrial and nuclear ribosomal DNA sequences and cross-breeding. Exp. Appl. Acarol. 1994, 18, 351-360. [CrossRef]

26. Vobis, M. Flöhe und Thre Molekularbiologische Charakterisier-ung. Diploma Thesis, Heinrich-Heine-University, Düsseldorf, Germany, 2002.

27. Lo, N.; Casiraghi, M.; Salati, E.; Bazzocchi, C.; Bandi, C. How many Wolbachia supergroups exist? Mol. Biol. Evol. 2002, 19, 341-346. [CrossRef]

28. Baldo, L.; Hotopp, J.C.D.; Jolley, K.A.; Bordenstein, S.R.; Biber, S.A.; Choudhury, R.R.; Hayashi, C.; Maiden, M.C.; Tettelin, H.; Werren, J.H. Multilocus sequence typing system for the endosymbiont Wolbachia pipientis. Appl. Environ. Microbiol. 2006, 72, 7098-7110. [CrossRef] 
29. Edgar, R.C. MUSCLE: Multiple sequence alignment with high accuracy and high throughput. Nucleic Acids Res. 2004, 32, 1792-1797. [CrossRef] [PubMed]

30. Librado, P.; Rozas, J. DnaSP v5: A software for comprehensive analysis of DNA polymorphism data. Bioinformatics 2009, 25, 1451-1452. [CrossRef] [PubMed]

31. Tamura, K.; Stecher, G.; Peterson, D.; Filipski, A.; Kumar, S. MEGA6: Molecular evolutionary genetics analysis version 6.0. Mol. Biol. Evol. 2013, 30, 2725-2729. [CrossRef] [PubMed]

32. Clement, M.; Posada, D.; Crandall, K.A. TCS: A computer program to estimate gene genealogies. Mol. Ecol. 2000, 9, 1657-1659. [CrossRef] [PubMed]

33. Leigh, J.W.; Bryant, D. PopART: Full-feature software for haplotype network construction. Methods Ecol Evol. 2015, 6, 1110-1116. [CrossRef]

34. Jolley, K.A.; Bray, J.E.; Maiden, M.C. Open-access bacterial population genomics: BIGSdb software, the PubMLST. org website and their applications. Wellcome Open Res. 2018, 3, 124. [CrossRef] [PubMed]

35. Verzhutsky, D.B. Spatial Organization of the Host Population and Its Ectoparasites; Palmarium Academic Publishing: Saarbrucken, Germany, 2012; p. 360. (In Russian)

36. Van der Mescht, L.; Matthee, S.; Matthee, C.A. New taxonomic and evolutionary insights relevant to the cat flea, Ctenocephalides felis: A geographic perspective. Mol. Phylogenetics Evol. 2021, 155, 106990. [CrossRef]

37. Zurita, A.; García-Sánchez, Á.M.; Cutillas, C. Ctenophthalmus baeticus boisseauorum (Beaucournu, 1968) and Ctenophthalmus apertus allani (Smit, 1955) (Siphonaptera: Ctenophthalmidae) as synonymous taxa: Morphometric, phylogenetic, and molecular characterization. Bull. Entomol. Res. 2020, 110, 663-676. [CrossRef]

38. Yudina, M.A.; Bykov, R.A.; Kotti, B.K.; Vysochina, N.P.; Stakheev, V.V.; Broshkov, A.D.; Zakharov, I.K.; Ilinsky, Y.Y. Wolbachia Infection in Flea Populations (Insecta: Siphonaptera). Biol. Bull. Rev. 2019, 9, 403-411. [CrossRef]

39. Nikitin, A.Y.; Nechaeva, L.K. Hybridization of flea subspecies as a possible basis for the method of regulating the number of vectors. Organization of plague surveillance and prevention measures. In Proceedings of the Interstate Scientific and Practical Conference, Almaty, Kazakhstan, 1992; Volume 3, pp. 400-403.

40. Nikitin, A.Y.; Bazanova, L.P.; Nechaeva, L.K.; Korzun, V.M.; Khabarov, A.V.; Kozets, L.I. Experimental study of the ability of hybrids bred from two subspecies of the flea Citellophilus tesquorum to transmit plague bacillus. Med. Parasitol. Parasit. Dis. 1995, 4, 15-17. (In Russian) 